\title{
IMPLIKASI MANAJEMEN PROGRAM BAHASA ARAB DALAM MENCETAK LULUSAN UNGGUL
}

\author{
Abdurrahman Shobirin', Danial Hilmi' \\ ${ }_{1}^{1}$ Pascasarjana Universitas Islam Negeri Maulana Malik Ibrahim Malang, Indonesia \\ ${ }^{2}$ Pascasarjana Universitas Islam Negeri Maulana Malik Ibrahim Malang, Indonesia \\ Email: abdurrahmanshobirin622@gmail.com ${ }^{1}$, danialhilmi@gmail.com²
}

\begin{tabular}{l|l|l} 
Received: Maret 2021 & Accepted: Juni 2021 & Published: Juli 2021
\end{tabular}

\begin{abstract}
Good program management refers to each function that has a role in improving the quality and quantity of the program. From some of its functions can have positive implications on the development of students of Arabic in accordance with the vision and mission set by an institution. Madrasah Aliyah Muhammadiyah 1 Plus Malang has several Arabic programs that can support student achievement and the program is packaged in an educational, constructive, and productive management. This study uses a descriptive qualitative approach to look for implications of the functions of Arabic program management consisting of planning, organizing, implementing, controlling, and evaluating. From several implications it was found that the terminology and commitment of Madrasah Aliyah Muhammadiyah 1 Plus Malang to the Arabic language program was able to deliver its graduates to become excellent and competent graduates to compete in the Arabic language field.
\end{abstract}

Keywords: Management, Arabic Program, excellence student

\begin{abstract}
Abstrak: Manajemen program yang baik mengacu pada masing-masing fungsinya yang berperan untuk meningkatkan kualitas dan kuantitas program. Dari beberapa fungsinya dapat memberikan implikasi yang positif pada perkembangan peserta didik terhadap bahasa Arab sesuai dengan visi misi yang telah ditetapkan oleh sebuah lembaga. Madrasah Aliyah Muhammadiyah 1 Plus Malang memiliki beberapa program bahasa Arab yang dapat menunjang prestasi siswa dan program tersebut dikemas dalam sebuah manajemen yang bersifat edukatif, konstruktif, dan produktif. Penelitian ini menggunakan pendekatan kualitatif deskriptif untuk mencari implikasi dari fungsi-fungsi manajemen program bahasa Arab yang terdiri dari perencanaan, pengorganisasian, implementasi, pengontrolan, dan evaluasi. Dari beberapa implikasi ditemukan bahwa keistiqomahan dan komitmen Madrasah Aliyah Muhammadiyah 1 Plus Malang terhadap program bahasa Arab mampu mengantarkan lulusannya menjadi lulusan yang unggul dan berkompeten untuk bersaing di bidang bahasa Arab.
\end{abstract}

Kata Kunci: Manajemen, Program Bahasa Arab, lulusan unggul 


\section{A. Pendahuluan}

Bahasa Arab memiliki beberapa kompetensi yang harus dicapai oleh siswa, di antaranya kompetensi linguistik dan non-linguistik. manajemen Program bahasa Arab mengampu beberapa kompetensi dengan kreativitas para petugas kependidikan dan penggunaan metode terkini oleh pendidik untuk mencapai beberapa tujuan dari program bahasa Arab.

Pengelolaan program yang baik dalam sebuah manajemen memberikan implikasi yang positif pada perkembangan peserta didik terhadap bahasa Arab sesuai dengan visi misi yang telah ditetapkan oleh sebuah lembaga. Manajemen program yang baik mengacu pada masing-masing fungsinya yang terdiri dari Perencanaan, Pengorganisasian, implementasi, Pengawasan, dan evaluasi. Nikles dan McHugh mengatakan bahwa manajemen adalah sebuah proses yang dilakukan untuk mewujudkan tujuan organisasi melalui rangkaian kegiatan berupa perencanaan, pengorganisasian, pengarahan, dan pengendalian orang-orang serta sumber daya organisasi lainnya. ${ }^{1}$

Beberapa lembaga pendidikan yang berbasis madrasah di Indonesia telah menoleh berbagai prestasi terhadap program bahasa Arab yang telah diterapkan. Di antaranya adalah Madrasah Aliyah Unggulan Nurul Islam Jember yang memperoleh prestasi yang gemilang pada olimpiade bahasa Arab tingkat provinsi Jawa Timur pada tanggal 03 Agustus 2019 di Surabaya. ${ }^{2}$ Kemudian, Madrasah Aliyah Negeri Islam Cendekia Kabupaten Siak Provinsi Riau memperoleh emas, perak, dan perunggu dalam ajang olimpiade bahasa Arab ke-III se-Indonesia yang diadakan pada tanggal 10 - 12 November 2019 di Jakarta. ${ }^{3}$

Beberapa prestasi yang diraih oleh kedua lembaga pendidikan tersebut berdampak pada antusianya mayoritas masyarakat muslim untuk menyekolahkan anak-anaknya ke madrasah yang memiliki program unggulan bahasa Arab. Sikap antusias tersebut dikarenakan kurikulum keagamaan yang berada di sekolah-sekolah negeri yang selain yang berbasis madrasah dan pesantren tidak memiliki bidang studi bahasa Arab.

Urgensi bahasa Arab tidak lagi hanya sebatas pembelajaran saja, melainkan berimplikasi pada pemahaman terhadap kajian-kajian keagamaan. Karena salah satu persyaratan seseorang dikategorikan sebagai ulama adalah mengerti dan memahami bahasa Arab sebagai bahasa al-Quran, Hadits, dan kitab-kitab agama lainnya yang ditulis dalam bahasa Arab. ${ }^{4}$

\footnotetext{
1 Wahyuddin, Manajemen Kurikulum, (Bandung: Rosdakarya, 2017), Hal. 05

2 Nurul Islam, Juara 1 Olimpiade Bahasa Arab Se-Jatim, Abdul Malik Lanjut Berjuang ke Tingkat Nasional, dalam https://pesantrennuris.net, diakses pada 22-11-2019

3 Public News, Hebat, 3 Pelajar MAN IC Siak Juara di Grand Final Olimpiade Bahasa Arab (OBA) 2019 seIndonesia, dalam https://publiknews.com , diakses pada 22-11-2019.

4 Ahmad Izzan, Metodologi Pembelajaran Bahasa Arab, (Bandung, Humaniora, 2011), Hal. 47
} 
Selain prestasi dalam kompetisi, bahasa Arab baru-baru ini juga menoleh prestasi dalam akademik. Dilansir oleh "Mata Hati” media komunitas malang raya pada tanggal 22 Mei 2019, memberitakan bahwa seorang siswa MA Muhammadiyah 1 Plus Malang raih predikat mumtaz pada nilai bahasa Arab se-Jawa Timur. ${ }^{5}$ Berita ini dibenarkan oleh pihak sekolah pada observasi awal tanggal 31 Oktober 2019 yang mengatakan bahwasannya siswa tersebut bernama Hamim Maulana yang mendapatkan nilai 100 pada Ujian Akhir Madrasah berstandar Nasional (UAMBN) bidang studi Bahasa Arab.

Dari isu terkini tentang prestasi akademik siswa pada bidang studi bahasa Arab, peneliti beranggapan bahwa di Madrasah Aliyah Muhammadiyah 1 Plus Malang memiliki beberapa program bahasa Arab yang dapat menunjang prestasi siswa dan program tersebut dikemas dalam sebuah manajemen yang bersifat edukatif, konstruktif, dan produktif.

Manajemen program yang ada di madrasah tersebut menarik peneliti untuk menkaji implikasi dari setiap aspek manajerial yang diterapkan dalam program bahasa Arab. Karena di dalamnya terdapat nilai-nilai positif yang dapat didistribusikan sebagai kaca perbandingan untuk peningkatan kualitas bahasa Arab bagi Madrasah itu sendiri dan Madrasah yang lainnya di seluruh Indonesia.

\section{B. Metode Penelitian}

Penelitian ini merupakan penelitian kualitatif deskriptif. kualitatif merupakan pendekatan yang menggunakan paradigma pengetahuan. ${ }^{6}$ Dan Deskriptif adalah penelitian yang hasil temuannya dideskripsikan secara sistematis, faktual, dan akurat. ${ }^{7}$ Penelitian kualitatif deskriptif adalah penelitian yang menggunakan paradigma pengetahuan dan hasil temuannya dideskripsikan secara sistematis, faktual, dan akurat. Maka penelitian ini akan mendeskripsikan tentang implikasi setiap aspek manajerial pada program bahasa Arab di MA Muhammadiyah 1 plus Malang dari segi Visi Misi, perencanaan, pengorganisasian, implementasi, pengontrolan, dan evaluasi.

Untuk memperoleh data penelitian, peneliti menggunakan wawancara dan dokumentasi. Wawancara adalah tanya jawab secara lisan baik langsung atau tidak langsung melalui tatap muka antara peneliti dan sumber data (responden). ${ }^{8}$ Adapun yang menjadi responden dalam penelitian ini adalah Kepala madrasah, Waka Kurikulum dan guru bidang studi bahasa Arab.

Dokumentasi adalah cara pengumpulan data melalui peninggalan tertulis seperti arsip-arsip dan termasuk juga buku-buku tentang pendapat, teori, dalil, hukum-hukum, dan lain-lain yang

5 Mata Hati, Siswa Mamumtaza Raih Mumtaz Nilai Bahasa Arab se-Jatim, dalam https://www.Matahatimalang.net , diakses pada 22-11-2-19

${ }^{6}$ Emzir, Metodologi Penelitian Pendidikan, (Jakarta: Rajawali Press, 2011), $\quad$ Hal. 28

${ }^{7}$ Triyono, Metodologi Penelitian Pendidikan, (Yogyakarta: Ombak Press, 2012), Hal. 44

${ }^{8}$ Triyono, Metodologi Penelitian Pendidikan, Hal. 162 
berhubungan dengan masalah penelitian. ${ }^{9}$ Adapun dokumen-dokumen yang diperlukan peneliti adalah Silabus, RPP, Nilai UAMBN bahasa Arab, arsip kegiatan ekstrakurikuler, dan arsip aktivitasaktivitas kebahasaan.

Teknik analisis data terdiri dari reduksi data, penyajian data, dan penarikan kesimpulan. Data-data yang diperoleh dari informan dan arsip disederhanakan dijadikan sebagai bahan penyajian data. Setelah data disajikan, peneliti menarik kesimpulan berdasarkan pada konsep teoritis yang ada.

\section{Hasil dan Pembahasan}

kata manajemen merupakan terjemahan dari bahasa inggris management. Management sendiri berasal dari kata to manage yang berarti mengelola. Dalam pengertian manajemen mengandung dua jenis kegiatan, yaitu kegiatan pikir dan kegiatan tingkah laku. Manajemen program bahasa Arab terkategori sebagai kegiatan pikir dan tingkah laku yang prosesnya terdiri dari perencanaan, pengorganisasian, implementasi, pengontrolan, dan evaluasi.

Proses manajemen program bahasa Arab berimplikasi pada nama baik lembaga dan lulusan peserta didiknya karena fungsi manajemennya diperhatikan secara benar. Implikasi secara bahasa artinya Keterlibatan. ${ }^{10}$ Secara istilah implikasi adalah dampak atau efek dari suatu objek yang mendapat perlakuan secara sengaja atau tidak sengaja pada waktu tertentu. ${ }^{11}$ implikasi program bahasa Arab adalah keterlibatan bahasa Arab terhadap peserta didik, pendidik, dan tenaga kependidikan dalam upaya membentuk lingkungan berbahasa untuk mencapai beberapa tujuan program.

MA Muhammadiyah I plus Malang (MAMUMTAZA) berasal dari pendidikan guru agama lengkap (PGAL) yang berdiri pada tahun 1954 di jalan Bandung (sekarang UMM kampus I). Berlandaskan SKMA RI 1978 tentang penghapusan seluruh sekolah yang diberi nama PGA negeri/swasta harus dihapus atau digantikan, sehingga PGAL berubah menjadi MA Muhammadiyah I Malang dengan piagam No. 1356/III0/jtm-75/1978 tanggal 6 November 1978.

Sejak tahun 2014, MAMUMTAZA Malang giat meningkatkan kemampuan bahasa asing dan keagamaan peserta didiknya melalui 3 program unggulan yaitu: (1) English Program, (2) Arabic Program, dan (3) Study Islam Intensive. Buah dari kerja keras melalui 3 program unggulan ini mulai terlihat pada tahun 2016, dimana MAMUMTAZA Malang mulai meraih prestasi membanggakan mulai tingkat kota hingga tingkat nasional dan dipercaya menjadi salah satu MUHAMMADIYAH EXCELLENT SCHOOL pada tahun 2018.

\footnotetext{
${ }^{9}$ Margono, Metodologi Penelitian Pendidikan, (Jakarta: Rineka Cipta, 2010), Hal. 181

${ }^{10} \mathrm{KBBI}$, dalam https://kbbi-web-id.cdn. Diakses 22-11-2019

${ }^{11}$ Wikipintar, Pengertian Implikasi, dalam http://wikipintar.com , diakses

22-11-2019
} 
Dilihat dari beberapa peningkatan kemampuan pada program unggulan, madrasah tersebut memiliki visi untuk menjadi madrasah yang unggul dalam sains dengan dasar bahasa Arab, Bahasa Inggris, serta berketerampilan. Dan misi madrasah yang terdiri dari:

1. Memupuk minat dan bakat siswa sehingga setiap siswa dapat berkembang sesuai dengan potensi yang dimiliki.

2. Membentuk siswa untuk berakhlakul karimah.

3. Menciptakan lingkungan bersih dan agamis.

4. Membentuk pola pikir kritis dan ilmiah.

5. Menumbuhkan dan menjaga sikap disiplin serta bertanggung jawab dalam masyarakat.

6. Menciptakan suasana belajar siswa aktif dengan berbasis IT.

7. Meningkatkan keterampilan serta kemampuan berbahasa Arab dan Inggris. ${ }^{12}$

Ditinjau dari visi yang telah dirancang oleh pihak madrasah peneliti melihat adanya integrasi antara sains dan agama, karena di madrasah tersebut bahasa Arab dijadikan sebagai salah satu landasan dasar untuk mencapai keunggulan di setiap bidang ilmu pengetahuan. integrasi keilmuan adalah "integration of sciences means the recognition that all true knowledge is from Allah and all sciences should be treated with equal respect whether it is scientific or revealed". ${ }^{13}$ kepala madrasah Muzainah memberikan tanggapan yang berkaitan dengan visi Madrasah bahwasannya untuk membentuk madrasah yang unggul, kreatif, dan religius diperlukan dasar yang kuat dalam menekuni beberapa bidang ilmu pengetahuan, salah satunya adalah bahasa Arab. ${ }^{14}$

Untuk mewujudkan beberapa misi yang ada di madrasah tersebut, kependidikan madrasah membentuk beberapa program bekerjasama dengan para pendidik untuk mengkonstruksi kreativitas dan probabelitas intelektual dalam bidang yang diminati oleh masing-masing peserta didik yang mana pada setiap aspek manajerial program tersebut berimplikasi pada individu peserta didik dan madrasah itu sendiri. Diantara beberapa program yang berimplikasi adalah program bahasa Arab.

\section{Perencanaan Program Bahasa Arab}

Pelaksanaan manajemen diawali dengan perencanaan-perencanaan yang melibatkan usaha manusia dengan bantuan manusia lain serta sumber-sumber lainnya untuk mencapai tujuan yang ditentukan dengan menggunakan metode yang efisien dan efektif. ${ }^{15}$

Perencanaan program adalah proses mempersiapkan keperluan suatu kegiatan guna mencapai tujuan yang telah ditetapkan. Untuk mencapai tujuan dari visi misi madrasah diperlukan

\footnotetext{
${ }^{12}$ Arsip Madrasah, diambil pada 21-11-2019 di Madrasah Aliyah Muhammadiyah 1 plus Kota Malang.

${ }^{13}$ Arifuddin, Konsep Integrasi Ilmu dalam Pandangan Isma'il Raji al-Faruqi, Jurnal Syamil, Vol.3 NO. 1,

${ }^{14}$ Wawancara Kepala Madrasah Aliyah Muhammadiyah 1 Plus Kota Malang pada 21-11-2019.

${ }^{15}$ Hamalik, Manajemen Pengembangan Kurikulum, (Bandung: Rosdakarya, 2012), Hal. 16
} 2015, hal. 47 
beberapa perencanaan program-program bahasa Arab di MA Muhammadiyah 1 plus Malang yang terdiri dari :

1. Membentuk kesungguhan dalam merumuskan beberapa tujuan program bahasa Arab.

2. Mengadakan pembinaan guru bahasa Arab dengan mengikut pelatihan-pelatihan.

3. Membentuk program reguler dan takhasus.

Tujuan dari perencanaan-perencanaan tersebut untuk penataan dan pemetaan program yang berimplikasi pada pelaksanaannya dengan membentuk beberapa kegiatan yang bersifat kurikuler dan ekstrakurikuler. Kegiatan yang bersifat kurikuler yaitu mengadakan kelas reguler dan kelas takhasus dalam pembelajaran untuk kebutuhan akademik. Sedangkan yang bersifat ekstra kurikuler, mengadakan kelas olimpiade untuk persiapan kompetisi.

Di samping pengadaan kegiatan kurikuler dan ekstrakurikuler, madrasah tersebut juga mengadakan beberapa aktivitas yang mendukung perkembangan pelaksanaan program bahasa Arab, di antaranya : (1) pembagian kosakata setiap setelah shalat Ashar, (2) kultum berbahasa Arab seminggu sekali, dan (3) kelas bahasa Arab untuk pada pendidik.

\section{Pengorganisasian Program Bahasa Arab}

Pengorganisasian sebagai sebuah proses dalam manajemen program yang terdiri dari beberapa tahapan, diantaranya: (1) menentukan tugas-tugas yang harus dilakukan, (2) membagi tugas-tugas pekerjaan yang akan dilaksanakan oleh perorangan atau kelompok, (3) menggabungkan pekerjaan secara rasional dan efisien, (4) menetapkan mekanisme pekerjaan, (5) monitoring untuk meningkatkan efektifitas. ${ }^{16}$

Program bahasa Arab di MA Muhammadiyah 1 plus malang melibatkan kepala madrasah, Wakil kepala Madrasah bidang kurikulum, kepala program unggulan bahasa Arab, dan kepala ruang laboratorium bahasa Arab yang masing-masing memiliki tugas untuk mengontrol, mengawal, dan mengevaluasi setiap kegiatan yang ada dalam program tersebut.

Indikator sekolah bermutu terdiri dari: (1) jumlah siswa yang banyak, (2) memiliki prestasi akademik dan non-akademik, dan (3) memiliki lulusan yang relevan.17 untuk menjadikan pendidik bahasa Arab bermutu yang berkualitas, diperlukan pendidik yang memiliki kualifikasi dan kompetensi yang multitalenta. Maka, hal tersebut berhubungan dengan manajemen rekrutmen guru bahasa Arab yang diorganisir oleh kepala madrasah dan wakil kepala madrasah bidang kurikulum.

Di madrasah tersebut pelaksanaan rekrutmen guru terdiri dari wawancara dan micro teaching. Wawancara dilaksanakan untuk mengetahui seberapa besar presentase kualifikasi calon

${ }^{16}$ Istikomah, Implementasi Fungsi Manajemen Pendidikan; Studi Kasus di MAN Insan Cendekia Jambi, Jurnal Pendidikan Islam, Vol. 7, No. 2, 2018, Hal. 2016.

${ }^{17}$ A. Aziz, Peningkatan Mutu Pendidikan, Jurnal Studi Islam, Vol. 10, No. 2, 2015, Hal. 01 
pendidik terhadap pengetahuannya tentang pendidikan bahasa Arab. Dan adapun micro teaching dilakukan untuk mengetahui seberapa besar penguasaan pendidik terhadap empat kompetensi pendidik, yaitu kepribadian, pedagogik, keprofesionalan, dan sosial.18

Calon pendidik bahasa Arab yang lolos seleksi diikutsertakan dalam beberapa pelatihan guru Bahasa Arab yang menghadirkan native speaker dari Arab secara langsung. Maka, dalam seleksi tersebut keakuratan nilai wawancara lebih tinggi dari pada microteaching. Hal ini berimplikasi pada cara mendidik para pendidik bahasa Arab yang mampu membentuk karakter peserta didik menjadi seorang pelajar yang berkompeten di bidang bahasa Arab secara akademik maupun nonakademik.

Kepala madrasah MA Muhammadiyah 1 Plus Malang ikut andil dalam menyeleksi dan mewawancarai calon guru bidang studi bahasa Arab untuk menguji komitmen dan konsistensinya terhadap visi misi madrasah. Wakil madrasah bidang kurikulum dan kepala program unggulan bahasa Arab menyusun beberapa kegiatan dalam program bahasa Arab yang akan dilaksanakan oleh para guru bidang studi bahasa Arab setelah melewati beberapa tahap penyeleksian. Dan kepala ruang Laboratorium Bahasa Arab mengatur jadwal masuk laboratorium yang dikoordinir oleh guru tersebut dan mengawasi beberapa fasilitas yang ada di dalamnya. Masing-masing tugas terlaksanakan dengan baik sehingga berimplikasi pada implementasi program yang berjalan dengan sistematis, efektif, dan efisien.

\section{Implementasi Program Bahasa Arab}

Kegiatan program bahasa Arab di MA Muhammadiyah 1 plus Malang terdiri dari kegiatan kurikuler dan ekstrakurikuler. Kegiatan kurikuler merupakan kegiatan yang dilaksanakan mengikuti kurikulum yang telah ditetapkan. Adapun kegiatan ekstrakurikuler adalah kegiatan yang dilaksanakan berdasarkan pada minat dan bakat peserta didik.

Kurikulum yang diterapkan dalam bidang studi bahasa Arab mengikuti KMA tahun 2016 tentang kurikulum 2013. Dengan demikian, pelaksanaan kurikuler pada program bahasa Arab, untuk jurusan IPA dan IPS diklasifikasikan ke dalam kelas reguler dan untuk jurusan bahasa ke dalam kelas takhasus yang terdiri dari kelas mubtadi', mutawasith, dan mutaqoddim.

Kelas mubtadi dan mutawasith menggunakan produk modul tersendiri hasil karya Nadia $A f$ Idati guru bidang studi bahasa Arab yang merangkap wakil kepala madrasah bidang kurikulum. Dan untuk kelas mutaqaddim menggunakan Arabiyah Baina Yadaik dan Arabiyah li an-nasyiin. Pengampu kelas mutaqoddin adalah Bustanul Firdaus, alumni LIPIA Jakarta yang juga merangkap sebagai Ketua bidang program unggulan bahasa Arab madrasah. Dengan adanya pengklasifikasian kelas dalam program bahasa Arab yang diampu oleh para pendidik yang berkualifikasi dalam

${ }^{18}$ Undang-undang Republik Indonesia No. 14 Tahun 2005 Tentang Guru dan Dosen, Hal. 06 
bidang bahasa Arab, maka pelaksanaan kurikulum tersebut berdampak pada peningkatan mutu madrasah yang dilihat dari prestasi peserta didik dan lulusan yang relevan.

Prestasi akademik dibuktikan oleh Hamim Maulana yang memperoleh nilai 100 dalam UNBK pada bulan Juni 2019 yang lalu, dan juga dibuktikan dengan lulusan madrasah yang melanjutkan studi ke timur tengah, yaitu: (1) Zahra Silma, Universita al-Azhar, Mesir, tahun 2017, dengan jalur non-beasiswa dan (2) Abdurrahman Hafizuddin, Universitas khortum, Sudan, tahun 2017, dengan jalur beasiswa kemenag.

Pembelajaran bahasa Arab bertujuan untuk menguasai empat keterampilan berbahasa yang terdiri dari istima', kalam, qira'ah, dan kitabah. ${ }^{19}$ Pada kelas reguler metode yang digunakan adalah saintifik method sesuai dengan KMA tahun 2016 tentang K-13. Berbeda dengan kelas takhasus yang mana tujuan utamanya adalah menguasai empat keterampilan berbahasa, sehingga dalam pedagogiknya menggunakan berbagai macam metode, diantaranya: direct method, communicative approach, dan reading method. Pada kelas takhasus pembelajaran bahasa Arab diawali dengan membaca, kemudian dilanjutkan dengan menyimak, berbicara, dan menulis.

Pada kelas takhasus dibiasakan untuk banyak mendengar dan latihan, karena pada setiap penilaian semester diadakan ujian praktek untuk menguji psikomotorik peserta didik dalam berbahasa Arab dan hasilnya dicantumkan dalam raport khusus yang disampaikan kepada wali peserta didik. keterlibatan metode yang digunakan dan beberapa kegiatan tambahan yang dilaksanakan menjadikan peserta didik mampu mengikuti pembelajaran secara aktif dan efektif untuk mencapai beberapa indikator pembelajaran pada setiap jamnya.

Hasil pembelajaran dapat diketahui melalui evaluasi formatif dan sumatif. Evaluasi formatif untuk mengetahui sejauh mana siswa telah terbentuk setelah mengikuti program tertentu. Sedangkan evaluasi sumatif untuk mengetahui perkembangan siswa setelah mengikuti program selama satu semester. ${ }^{20}$ Berdasarkan pada arsip evaluasi pembelajaran bahasa Arab hal tersebut dibuktikan dengan persentase rata-rata nilai sumatif $88 \%$ dan persentase rata-rata nilai formatif $86 \%$.

Ekstrakurikuler merupakan salah satu kegiatan peserta didik di luar jam kurikuler / jam pelajaran berdasarkan pada minat dan bakatnya masing-masing. ${ }^{21}$ Dalam program bahasa Arab terdapat ekstrakurikuler kelas olimpiade bahasa Arab yang terdiri dari khitobah dan taqdimu alqishoh. Peserta pada ekstrakurikuler ini sebagian besar berasal dari kelas takhasus, sehingga implikasinya sama dengan kurikulum yang berkaitan dengan peningkatan mutu madrasah dalam

19 M. Thoha, Pembelajaran Bahasa Arab dengan Pendekatan Manajemen Berbasis Sekolah, Jurnal OKARA, Vol. 1, No. 7, 2017, Hal. 82

${ }^{20}$ Arikunto, Dasar-Dasar Evaluasi Pendidikan, (Jakarta: Bumi Aksara, 2013), Hal. 50-53

${ }^{21}$ R. Y. Lestari, Peran Kegiatan Ekstrakurikuler dalam Mengembangkan Watak Kewarganegaraan Peserta Didik, Untirta Civic Education Jurnal, Vol. 1, No. 2, 2016, Hal. 137 
bidang bahasa Arab. Hal tersebut dibuktikan dengan beberapa prestasi non-akademik peserta didik sebagaimana ditampilkan pada gambar 1.

Tabel 1. Prestasi Non-Akademik Peserta Didik

\begin{tabular}{lclc}
\hline No & Nama & \multicolumn{1}{c}{ Prestasi } & Tingkat \\
\hline 1 & Hamim Maulana Rahman & $\begin{array}{l}\text { Finalis tingkat provinsi olimpiade } \\
\text { bahasa Arab tahun 2017 }\end{array}$ & Nasional \\
\hline 2 & M. Naufal Rahman & $\begin{array}{l}\text { Finalis tingkat provinsi olimpiade } \\
\text { bahasa Arab tahun 2017 }\end{array}$ & Nasional \\
\hline 3 & Adinda Rizki Al-Urfi & $\begin{array}{l}\text { Finalis tingkat provinsi olimpiade } \\
\text { bahasa Arab tahun 2017 }\end{array}$ & Nasional \\
\hline 4 & Zahra Silma Ramadhania & $\begin{array}{l}\text { Juara 1 Olimpiade ISMU in Arabic } \\
\text { tahun 2017 }\end{array}$ & Jawa Bali \\
\hline 5 & Silvia Ummaratuz Zahra & $\begin{array}{l}\text { Jara 4 pidato bahasa Arab pelajar } \\
\text { PBA UIN malang tahun 2017 }\end{array}$ & Nasional \\
\hline 6 & Zahra Silma Ramadhania & $\begin{array}{l}\text { Medali perak Olimpiade ISMU in } \\
\text { Arabic tahun 2017 }\end{array}$ & Nasional \\
\hline 7 & Khorik Hayati & $\begin{array}{l}\text { Special Award ISMU in Arabic } \\
\text { tahun 2018 }\end{array}$ & Jawa Bali \\
\hline
\end{tabular}

Aktivitas kebahasaaan di MA Muhammadiyah 1 plus Malang sangat mendukung tujuan dari program bahasa Arab yang terdiri dari beberapa aktivitas kebahasaan untuk pendidik dan peserta didik. Setiap hari jum'at sore, para pendidik mengikuti kelas bahasa Arab guna untuk menambah wawasan kebahasaan dan beberapa kosakata.

Adapun kegiatan kebahasaan untuk peserta didik terdiri dari pembagian kosakata bahasa Arab dua kali dalam seminggu dan kultum berbahasa Arab sekali dalam seminggu. Kegiatan tersebut diadakan di masjid dan diikuti oleh seluruh peserta didik pada setiap jurusan. Kegiatan ini berkontribusi pada pembelajaran bahasa Arab di kelas dan pembentukan lingkungan berbahasa di madrasah, sehingga terjadi keseimbngan antara sains, agama, dan bahasa sesuai dengan visi misi madrasah.

Beberapa aktivitas kebahasaan yang dilaksanakan berupaya untuk memperkaya kosakata peserta didik untuk meningkatkan keterampilan berbahasa. Menurut Horn, "kosakata adalah sekumpulan kata yang membentuk sebuah bahasa". Peran kosakata dalam menguasai empat keterampilan berbahasa sangat diperlukan. Vallet mengatakan bahwa kemampuan seseorang untuk memahami empat keterampilan berbahasa sangat bergantung pada penguasaan kosakata yang dimiliki. ${ }^{22}$

\footnotetext{
61.
}

${ }^{22}$ Syaiful Musthofa, Strategi Pembelajaran Bahasa Arab Inovatif, (Malang: UIN Maliki Press, 2011), Hal. 
Beberapa aktivitas kebahasaan tersebut sangat besar kontribusinya terhadap pembentukan lingkungan berbahasa di madrasah, karena materi yang diberikan berhubungan dengan percakapan sehari-hari sehingga dapat diterapkan ketika bertemu dengan peserta didik.

\section{Evaluasi Program Bahasa Arab}

Evaluasi program merupakan proses pengumpulan data atau memberikan informasi tentang seberapa besar tingkat keberhasilan suatu program yang direncanakan, diorganisir, dilaksanakan, dan dikontrol oleh stakeholder yang bersangkutan. Kemudian informasi tersebut digunakan sebagai pertimbangan pengambilan keputusan untuk tindak lanjut program pada tahun berikutnya. ${ }^{23}$

Peserta didik MA Muhammadiyah 1 Plus Malang terdiri dari campuran antara lulusan SMP negeri, MTS Negeri dan pesantren, sehingga berdampak pada stabilitas pelaksanaan program bahasa Arab sehingga membutuhkan evaluasi untuk sebuah perbaikan. Evaluasi sebagai suatu proses penaksiran terhadap kemajuan, Pertumbuhan, dan perkembangan peserta didik untuk tujuan pendidikan. Fungsi evaluasi dalam manajemen adalah memberikan informasi terhadap beberapa aspek manajemen yang memerlukan perbaikan agar untuk perencanaan di pemrograman berikutnya terdapat peningkatan mutu secara kualitas dan kuantitas. Maka di madrasah tersebut setiap akhir tahun diadakan musyawarah kerja pemrograman kegiatan bahasa Arab untuk tahun berikutnya.

Musyawarah memberikan informasi bahwa diperlukannya kegiatan untuk meningkatkan kualitas dan kuantitas pendidik dalam menjalankan program, sehingga berimplikasi pada adanya workshop setiap awal tahun untuk pembuatan perangkat dan pelatihan dengan menghadirkan natif speaker untuk menambah kecakapan keterampilan berbahasa bagi pendidik.

\section{Kesimpulan}

Fungsi manajemen Program bahasa Arab di Madrasah Aliyah Muhammadiyah 1 plus malang terdiri dari Perencanaan, pengorganisasian, implementasi, pengontrolan, dan evaluasi yang masingmasing fungsi tersebut berimplikasi pada nama baik madrasah dan kualitas lulusan peserta didiknya. Perencanaan bertujuan untuk penataan dan pemetaan program yang berimplikasi pada terbentuknya beberapa kegiatan yang bersifat kurikuler dan eksrtrakurikuler. Program bahasa Arab di MA Muhammadiyah 1 plus malang melibatkan kepala madrasah, Wakil kepala Madrasah bidang kurikulum, kepala program unggulan bahasa Arab, dan kepala ruang laboratorium bahasa Arab yang masing-masing memiliki tugas dan terlaksana dengan baik sehingga berimplikasi pada implementasi program yang yang berjalan dengan sistematis, efektif, dan efisien.

23 S. C. O. Barusu, Studi Evaluasi Manajemen Pendidikan Perguruan Tinggi Berbasis Agama pada Universitas Kristen Tentena di Gereja Kristen Sulawesi Tengah, E-Journal Program Pascasarjana Universitas Pendidikan Ganesha, Vol. 05, 2014, Hal 03. 
Kegiatan program bahasa Arab di MA Muhammadiyah 1 plus Malang terdiri dari kegiatan kurikuler dan ekstrakurikuler yang terdiri dari beberapa aktivitas kebahasaan. Beberapa aktivitas tersebut sangat besar kontribusinya terhadap pembentukan lingkungan berbahasa di madrasah. Program Bahasa Arab di MA Muhammadiyah 1 plus Malang secara keseluruhan dimonitoring oleh kepala program unggulan bahasa Arab. Pengontrolan tersebut berjalan dengan baik sehingga berimplikasi pada stabilitas pelaksanaan program bahasa Arab dengan pemberian solusi aplikatif dalam setiap kendala.

Evaluasi program di madrasah tersebut dilakukan secara keseluruhan dari segi perencanaan, pengorganisasian, implementasi, dan pengontrolan dilakukan dalam musyawarah besar pada setiap akhir tahun sehingga berimplikasi pada adanya workshop setiap awal tahun untuk pembuatan perangkat dan pelatihan dengan menghadirkan native speaker untuk menambah kecakapan keterampilan berbahasa bagi pendidik

Dari beberapa fungsi manajemen program bahasa Arab yang telah dikemukakan, dideskripsikan beserta implikasinya, dan dianalisa mengacu kepada visi misinya ditemukan bahwa keistiqomahan dan komitmen Madrasah Aliyah Muhammadiyah 1 Plus Malang terhadap program bahasa Arab mampu mengantarkan lulusannya menjadi lulusan yang unggul dan berkompeten untuk bersaing di bidang bahasa Arab.

\section{Daftar Rujukan}

Aziz, A. (2015). peningkatan mutu pendidikan. Jurnal Studi Islam, Vol. 10, No. 2.

Arifuddin. (2015). Konsep Integrasi Ilmu dalam Pandangan Isma'il Raji al-Faruqi. Jurnal Syamil, Vol. 3, No. 1 .

Arikunto, S. (2013). Dasar-Dasar Evaluasi Pendidikan. Jakarta: Bumi Aksara.

Barusu, O. C. S. (2014). Studi Evaluasi Manajemen Pendidikan Perguruan Tinggi Berbasis Agama pada Universitas Kristen Tentena di Gereja Kristen Sulawesi Tengah. E-Journal Program Pascasarjana Universitas Pendidikan Ganesha, Vol. 05.

Emzir. (2011). Metodologi Penelitian Pendidikan. Jakarta: Rajawali press.

Hamalik, O. (2012). Manajemen Pengembangan Kurikulum. Bandung: Rosdakarya.

Izzan, A. (2011). Metodologi Pembelajaran Bahasa Arab. Bandung: Humaniora.

Istikomah. (2018). Implementasi Fungsi Manajemen Pendidikan; Studi Kasus di MAN Insan Cendekia Jambi. HIKMAH: Jurnal Pendidikan Islam, Vol. 07, Nomor 02.

KBBI. (2019). diakses Pukul 09.18 WIB pada https://kbbi-web-id.cdn.

Lestari, Y. R. (2016). Peran Kegiatan Ekstrakurikuler dalam Mengembangkan Watak Kewarganegaraan Peserta Didik. Untirta Civic Education Journal, Vol. 1, No. 2. 
Mata Hati. (2019). Siswa Mamumtaza Raih Mumtaz Nilai Bahasa Arab se-Jatim. diakses 08.48 WIB pada https://www.Matahati malang.net.

Margono. (2010). Metodologi Penelitian Pendidikan. Jakarta: Rineka Cipta.

Musthofa, S. (2011) Startegi Pembelajaran Bahasa Arab Inovatif. Malang: UIN Maliki Press.

Nurul Islam Jember. (2019). Juara 1 Olimpiade Bahasa Arab Se-Jatim, Abdul Malik Lanjut Berjuang ke Tingkat Nasional. diakses puku. 13.52 WIB pada https://pesantrennuris.net.

Publik News. (2019). Hebat, 3 Pelajar MAN IC Siak Juara di Grand Final Olimpiade Bahasa Arab (OBA) 2019 se-Indonesia. diakses pukul 13.57 WIB pada https://publiknews.com.

Thoha, M. (2017). Pembelajaran Bahasa Arab dengan Pendekatan Manajemen Berbasis Sekolah. Jurnal OKARA, Vol. 1, No. VII.

Triyono. (2012). Metodologi Penelitian Pendidikan. Yogyakarta: Ombak Press.

Undang-undang Republik Indonesia nomor 14 tahun 2005 tentang guru dan dosen.

Wahyudin, D. (2017). Manajemen Kurikulum. Bandung: Rosdakarya.

Wikipintar, (2019). Pengertian Implikasi, diakses pukul 09.26 WIB pada http://wikipintar.com. 